\title{
THE INFLUENCE OF ETHNOCENTRICITY IN PURCHASE BEHAVIOR AND ETHNOCENTRIC ATTITUDES
}

\author{
MARIA ELENA ARAMENDIA-MUNETA \\ UNIVERSIDAD PÚBLICA DE NAVARRA \\ JAMES REARDON \\ UNIVERSITY OF NORTHERN COLORADO
}

This research examines the effect of Consumer Ethnocentricity (CE) under conditions of persistent financial crisis. The conceptual underpinnings of $C E$ imply that consumers, at least some, respond to foreign goods negatively based on the idea of preserving the domestic economy. Thus, it would logically follow that when the economy is in recession or crisis, this phenomenon might be exaggerated. Spain is one of the areas most affected by the global economic crisis, and within this country, young students have been among the hardest hit. There are four hypotheses: Hla: Ethnocentric attitudes of consumers have a positive effect on Domestic Purchase Behavior; H1b: Ethnocentric attitudes of consumers have a negative effect on Foreign Purchase Behavior; H2: National Identification has a positive effect on Ethnocentricity; H3: Cosmopolitanism has a negative effect on Ethnocentricity. Hypotheses H1a, H1b, and H2 are supported while H3 is not supported.

Keywords: consumer ethnocentricity, purchase behaviour, domestic and foreign product, Spain

\section{Introduction}

Consumer Ethnocentrism (CE) models have been used to examine a host of country of origin (COO) issues over the last two decades. However, all the models imply or presume that the resultant effects are static as to environment. Yet, both reality and theory suggest otherwise. 
Consumers adapt to both the declines and increases in income. They also adjust to psychological factors related to consumption. Most recently, the global economic crisis has had a significant and persistent effect on consumers. However, there has been limited examination about the effects of this rather massive environmental factor on the psychology of consumers.

The EU has been perhaps the hardest hit by the global economic crisis. By 2008, Spain, Germany, and the UK had received more than half of all the immigrants in the EU27, that is more than 2 million (European Commission, 2008). However, given the current economic crisis in Spain, this evolution could change, and turn Spain into an emigrant country rather than an immigrant one. Spanish youth are concerned about the increasing rate of unemployment, which rose to 26 per cent in December 2012, according to Instituto Nacional de Estadística (Spain). It is in this context that consumers are adapting their consumption patterns. Given the global nature of the crisis, $\mathrm{CE}$ is used to examine both the domestic and foreign purchase propensity within the context of this persistent economic crisis.

Therefore, in this study, it is intended to measure whether Spanish youth have a critical attitude towards purchasing domestic or foreign products, as well as research the extent to which they have strong feelings of ethnocentrism or cosmopolitanism.

\section{Literature Review: Some Global Vision}

With globalization, countries, no matter how far apart they may be, are present in the lives of people, especially thanks to mass media and the Internet, thus people have their own view and image of a country through external influences (D'Astous \& Boujbel, 2007). The concept of COO started and gained relevance in the early 1960s (Lu \& Heslop, 2008; Roth \& Diamantopoulos, 2009), and since then more than 1000 works have been published on this topic (Papadopoulos, 2004).

Other researchers explain the effects of $\mathrm{COO}$ as part of a psychological process, likening it to a halo model (Han, 1989). This psychological process has an influence on consumers, especially in the case of those with no direct personal experience of having lived in or having visited a foreign country.

Consumers evaluate products based on the nation where they have been made, and this is a concept researched in depth (Singh, 2013; Nijssen \& Douglas, 2004; Granzin \& Olsen, 1998; Han, 1988; Shimp \& Sharma, 1987). Culture, ethnicity, and nation are concepts whose identities are inside the consumer and when markets change due to economic or 
political reason, these identities tend to become extremist (Herche, 1994; Vida \& Dmitrović, 2001).

Although we live in the age of globalization, this does not necessarily lead to homogenizing consumer behavior (De Mooij \& Hofstede, 2002). However, in an economic crisis, consumers may have more of a tendency to protect the domestic economy or likewise blame the global trade for the ills (Yeoh, 2013). This study aims to identify consumer preferences between domestic and foreign products in the Spanish market, and attempts to contrast a model of ethnocentric attitudes.

\section{Conceptual Development}

\section{Ethnocentric Attitudes}

Shimp \& Sharma (1987) described consumer ethnocentrism as the way in which consumers view their products as far superior to the foreignmade products. With this attitude, consumers enhance their feelings of patriotism and truly believe that this behavior can aid development of the domestic economy and foster employment. Then Sharma, Shimp, and Shin in 1995 created a model to understand this phenomenon. They made suggestions on a number of factors with the purpose of explaining how ethnocentrism adapts itself to consumerism (for example, culture, patriotism, demography, general economic conditions, characteristic of consumer, etc.). These variables were confirmed as key factors of influence in consumer ethnocentrism (Balabanis, Diamantopoulos, Mueller \& Melewar, 2001; Herche, 1994; Kaynak \& Cavusgil 1983; Reardon, Miller, Vida \& Kim, 2005; Shankarmahesh, 2006; Yelkur, Chakrabarty \& Bandyopadhyay, 2006; Wang \& Chen, 2004).

Not only does ethnocentricity have a deep impact on consumers, but also on the $\mathrm{COO}$ when consumers buy a product (Balabanis \& Diamantopoulos, 2004). COO favors this ethnocentric attitude and this could even have a negative effect on domestic/foreign purchase behavior (Balabanis \& Diamantopoulos, 2004; Suh \& Kwon, 2002). However, there are some researchers who suggest that product quality is a notable aspect for less ethnocentric consumers. Therefore, $\mathrm{COO}$ also affects the perception of a product in consumerism. It must also be highlighted that $\mathrm{COO}$ has an influence on quality perception of a product (Balabanis \& Diamantopoulos, 2004; Bilkey \& Nes, 1982; Brodowsky, 1998; Herche, 1994) as well as on the image of the country. Consumers tend to evaluate products more favorably or less favorably, depending on that image or perception (Liu \& Johnson, 2005). Thus: 
H1a: Ethnocentric attitudes of consumers have a positive effect on Domestic Purchase Behavior

H1b: Ethnocentric attitudes of consumers have a negative effect on Foreign Purchase Behavior

\section{Antecedents of Ethnocentric Attitudes}

The concept of ethnocentricity is related to several socio-psychological factors, such as culture, nation, and unique historical identity (Costa \& Bamossy, 1995; Cui \& Adams, 2002; Keillor, Hult, Erffmeyer, \& Babakus, 1996; Suh \& Kwon, 2002).

However, there is no consensus among the researchers about the real sources of consumer ethnocentricity. Some of them, such as Javalgi, Khare, Gross \& Scherer (2005), de Ruyter, Van Birgelen \& Wetzels (1998), and Sharma et al. (1995), agree that patriotism, cultural openness, individualism, and conservatism are the main sources of consumer ethnocentricity. While others, such as Balabanis et al. (2001), have reached an understanding about the insignificant effect of internationalism on patriotism and nationalism. So:

H2: National Identification has a positive effect on Ethnocentricity

H3: Cosmopolitanism has a negative effect on Ethnocentricity

\section{Model}

The framework of the model (Figure 1) is based on Auruskeviciene, Vianelli \& Reardon (2012), where consumer ethnocentrism is the main connector. From one side, cosmopolitan and national identity influence the consumer ethnocentrism and then this main connector impacts the buying of domestic or foreign products.

\section{Sample}

The sample consisted of 564 respondents from the north of Spain. College students were chosen as subjects, based on the following factors: a) relative homogeneity of extraneous influences (Burgess \& Steenkamp, 2006; Coulter, Price, Feick \& Micu, 2005; Strizhakova, Coulter \& Price, 2008 ); b) relatively higher exposure to global commerce (Gidley, 2002; Kjeldgaard \& Askegaard, 2006); and c) relatively higher exposure to multiple languages/cultures (Aramendia-Muneta, Galarza-Lanz \& MañasLarraz, 2012). 


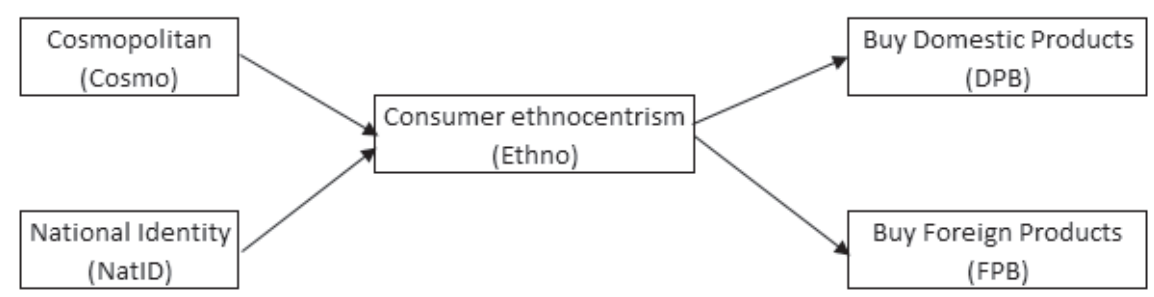

Figure 1: Ethnocentrism Model (Auruskeviciene et al., 2012)

\section{Methodology Issues}

\section{Measures}

Construct measures for this research were derived from existing literature (Granzin \& Olsen, 1998; Keillor et al., 1996; Parameswaran \& Pisharodi, 1994; Yoon, Cannon \& Yaprak, 1996). All measures used have been proven psychometrically sound in cross-cultural contexts. CETSCALE, for example, has been previously used and validated in various cross-cultural contexts (for example, Lindquist, Vida, Plank \& Fairhurst, 2001; and Good \& Huddleston, 1995). For this study, the sixitem version of the original scale was utilized to measure ethnocentrism. Seven-point Likert-type scales $(1=$ strongly disagree to $7=$ strongly agree $)$ were utilized for the individual scales to measure the five constructs.

In the process of translation and cross-cultural adaptation of the research stimuli and questionnaire (scale items), we followed the guidelines for conducting international consumer research by Craig \& Douglas (1999) and by Douglas \& Craig (2006).

Reliability of the scales was established using Cronbach's Alpha (see Table 1). All alpha values are "respectable or better", that is higher than 0.7 (DeVellis, 2003). 
Table 1: Measures

\begin{tabular}{|c|c|}
\hline Constructs/Items & Reliability(Alpha) \\
\hline $\begin{array}{l}\text { National Identification (Nat ID) (Adapted from Keillor et al., } \\
\text { 1996 ) } \\
\text { 1. Being a Spanish citizen means a lot to me } \\
\text { 2. I am proud to be a Spanish citizen } \\
\text { 3. When a foreign person praises Spain, it feels like a personal } \\
\text { compliment } \\
\text { 4. I feel strong ties with Spain }\end{array}$ & 0.944 \\
\hline $\begin{array}{l}\text { Cosmopolitanism (Cosmo) (Adapted from Yoon et al., 1996) } \\
\text { 1. I like immersing myself in different cultural environments } \\
\text { 2. I like having contact with people from different cultures } \\
\text { 3. I would enjoy travelling to foreign countries for an extended } \\
\text { period of time } \\
\text { 4. Getting information and news from around the world is } \\
\text { important to me }\end{array}$ & 0.836 \\
\hline $\begin{array}{l}\text { Ethnocentricity (Ethno) (Adapted from Shimp and Sharma, } \\
\text { 1987) } \\
\text { 1. Only those products that are unavailable in Spain should be } \\
\text { imported } \\
\text { 2. Spanish products, first, last, and foremost } \\
\text { 3. A real Spanish citizen should always buy Spanish-made } \\
\text { products } \\
\text { 4. Spanish citizens should not buy foreign products, because } \\
\text { this hurts Spain's businesses and causes unemployment } \\
\text { 5. It may cost me in the long-run, but I prefer to support } \\
\text { 6. Spanish products } \\
\text { Spanish consumers who purchase products made in other } \\
\text { countries are responsible for putting their fellow Spanish } \\
\text { citizens out of work }\end{array}$ & 0.876 \\
\hline $\begin{array}{l}\text { Domestic Purchase Behaviour (DPB) (Adapted from Granzin } \\
\text { and Olsen, 1998) } \\
\text { 1. I try to buy mostly domestic brands } \\
\text { 2. I take time to look at labels in order to knowingly buy more } \\
\text { domestic brands } \\
\text { 3. I shop at retail stores that make a special effort to offer } \\
\text { domestic brands }\end{array}$ & 0.844 \\
\hline $\begin{array}{l}\text { Foreign Purchase Behaviour (FPB) (Adapted from Granzin } \\
\text { and Olsen, 1998) } \\
\text { 1. I like the idea of owning foreign products } \\
\text { 2. My quality of life would improve if more imported goods } \\
\text { were available } \\
\text { 3. I find imported goods more desirable than domestically } \\
\text { produced products }\end{array}$ & 0.749 \\
\hline
\end{tabular}




\section{Results and Discussion}

The estimation and the t-test results are shown in Figure 2 below.

As indicated below in Table 2, the overall fit of the model is acceptable. As could be expected, given the sample size, the Chi-Squared statistic was significant. The other performance measures suggest that our model describes the data well within the acceptable limits, as shown in Table 3. The RMSEA was below the 0.08 cutoff value suggested by Browne \& Cudeck (1993). In addition, the CFI is above the commonly recommended 0.90 limit (Lichtenstein, Ridgway \& Netemeyer, 1992).

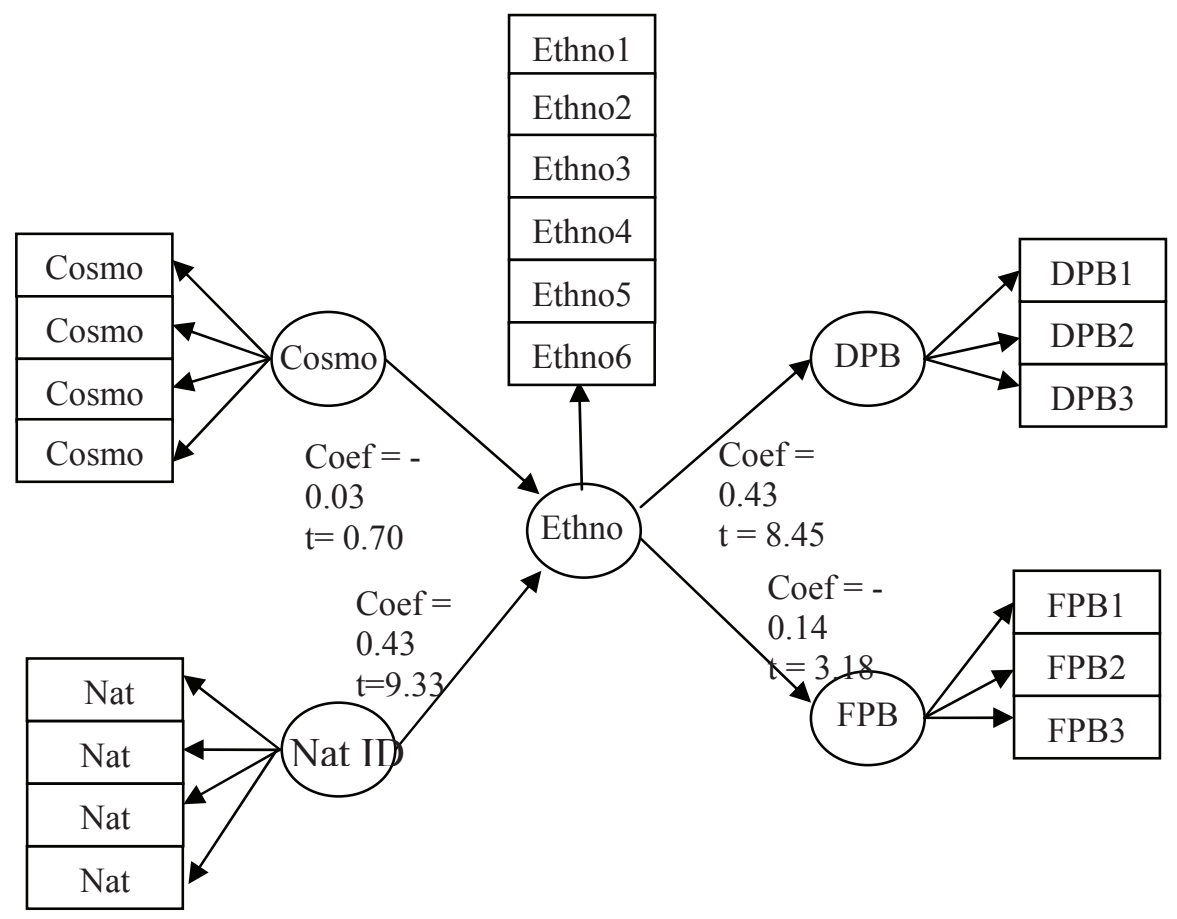

Figure 2: Estimation and T-Test Results 
Tables 2: Overall Fit of the Model

\begin{tabular}{|l|c|}
\hline Chi-Squared & $527.13 \mathrm{df}=165$ \\
RMSEA & 0.063 \\
CFI/IFI & 0.96 \\
NFI & 0.95 \\
RFI & 0.94 \\
\hline
\end{tabular}

The hypotheses are tested by examining the individual structural paths of the model (Table 3).

Table 3: Hypotheses Results

\begin{tabular}{|c|c|c|c|c|}
\hline Hypotheses & Linkage & Estimate & $\begin{array}{c}\text { t/p- } \\
\text { value }\end{array}$ & Result \\
\hline H1a: & $\begin{array}{c}\text { Ethno } \rightarrow \text { DPB } \\
(+)\end{array}$ & 0.43 & $8.45^{*}$ & Supported \\
\hline H1b: & $\begin{array}{c}\text { Ethno } \rightarrow \text { FPB } \\
(-)\end{array}$ & -0.14 & $3.18^{*}$ & Supported \\
\hline H2: & $\begin{array}{c}\text { Nat ID } \rightarrow \\
\text { Ethno (+) }\end{array}$ & 0.43 & $9.33^{*}$ & Supported \\
\hline H3: & $\begin{array}{c}\text { Cosmo } \rightarrow \\
\text { Ethno (-) }\end{array}$ & -0.03 & 0.70 & Not Supported \\
\hline$*=p<0.05$ & \multicolumn{3}{|l}{} \\
\hline
\end{tabular}

Overall, all the hypotheses except $\mathrm{H} 3$ are supported. It apparently seems that Spanish youth own a sense of ethnocentricity. Actually, ethnocentric attitudes and national identification have a positive effect on domestic purchase behaviour. Living in an international atmosphere, having contact with people from different cultures, and travelling to foreign countries for a long period of time are factors that have neither a negative impact nor a positive one on ethnocentricity.

The hypothesized negative effect of ethnocentric attitudes on the foreign purchase behavior was confirmed. The influence of foreign brands and products has no effect on the purchase of domestic brands and products. Spanish youth tend to buy domestic products instead of foreign ones. The "made in Spain" label favors domestic purchase behaviour and increases local bonds and attachment. 


\section{Limitations and Future Research}

The obvious limitations are the sample (students) and single country analysis - but that really was the purpose of this research, that is to concentrate on local conditions. Furthermore, the study does not take into account variables such as the current economic situation in Spain and the high rate of unemployment among the target group (youth). The selection of this target group is consistent with an economic strategy known as Europe 2020, which emphasizes three elements that are important for the future of Europe: youth, education, and mobility (European Commission, 2010).

In the last four years, the Spanish national football team won two European championships and the World championship. As football is the first sport in Spain, those victories may have had a great impact on national identity. In fact, the national flag and the national football team shirt are quite commonly seen in the Spanish territory. Therefore, it would be worth researching the football effect on ethnocentricity and nationalism.

These results could be improved in the future by expanding the sample to other places in the Spanish territory, as well as by researching other collectives of consumers and not only youth.

\section{References}

Aramendia-Muneta, M. E., Galarza-Lanz, J. R., \& Mañas-Larraz, M. (2013). 'e-Bridge to mobility: A non-formal online learning European platform.' In H. H. Yang, \& S. Wang (Eds.), Cases on formal and informal E-learning environments: Opportunities and practices (pp. 81-100). Hershey, PA: IGI Global.

Auruskeviciene, V., Vianelli, D., \& Reardon, J. (2012). 'Comparison of consumer ethnocentrism behavioural patterns in transitional economies.' Transformations in Business and Economics, 11(2/26), 20-35.

Balabanis, G., \& Diamantopoulos, A. (2004). 'Domestic country bias, country-of-origin effects, and consumer ethnocentrism: A multidimensional unfolding approach.' Journal of the Academy of Marketing Science, 32(1), 80-95.

Balabanis, G., Diamantopoulos, A., Mueller, R. D., \& Melewar, T. (2001). 'The impact of nationalism, patriotism and internationalism on consumer ethnocentric tendencies.' Journal of International Business Studies, 32(1), 157-75. 
Bilkey, W.J., \& Nes, E. (1982). 'Country-of-origin effects on product evaluations.' Journal of International Business Studies, 13(1), 89-99.

Brodowsky, G.H. (1998). 'The effects of country of design and country of assembly on evaluative beliefs about automobiles and attitudes toward buying them: A comparison between low and high ethnocentric consumers.' Journal of International Consumer Marketing, 10(3), 85113.

Browne, M.W., \& Cudeck, R. (1993). 'Alternative ways of assessing model fit.' In K. A. Bollen, \& J. S. Long (Eds.), Testing structural equation models (pp. 136-162). Newbury Park, CA: Sage Publications.

Burgess, S.M., \& Steenkamp, J.E. (2006). 'Marketing renaissance: How research in emerging markets advances marketing science and practice.' International Journal of Research in Marketing, 23(4), 337356.

Costa, J. A., \& Bamossy, G.J. (1995). Marketing in a multicultural world: Ethnicity, nationalism, and cultural identity. Thousand Oaks, CA: Sage Publications.

Coulter, R. A., Price, L.L., Feick, L., \& Micu, C. (2005). 'The evolution of consumer knowledge and sources of information: Hungary in transition.' Journal of the Academy of Marketing Science, 33(4), 60419.

Craig, C.S., \& Douglas, S.P. (2005). International marketing research. New York, NY: John Wiley \& Sons, Ltd.

Cui, C.C., \& Adams, E. I. (2002). 'National identity and NATID: An assessment in Yemen.' International Marketing Review, 19(6), 637-62.

D'Astous, A., \& Boujbel, L. (2007). 'Positioning countries on personality dimensions: Scale development and implications for country marketing.' Journal of Business Research, 60(3), 231-39.

De Mooij, M., \& Hofstede, G. (2002). 'Convergence and divergence in consumer behaviour: Implications for international retailing.' Journal of Retailing, 78(1), 61-9.

De Ruyter, K., Van Birgelen, M., \& Wetzels, M. (1998). 'Consumer ethnocentrism in international services marketing.' International Business Review, 7(2), 185-202.

DeVellis, R.F. (2003). Scale development: Theory and applications (2nd ed.). Thousand Oaks: Sage Publications.

Douglas, S.P., \& Craig, C.S. (2006). 'On improving the conceptual foundations of international marketing research.' Journal of International Marketing, 14(1), 1-22.

European Commission (2008). Eurostat EU Labour Force Survey. Brussels, EU. 
-. (2010). Europe 2020. A strategy for smart, sustainable and inclusive growth. Brussels, EU.

Gidley, J. (2002). 'Global youth culture: A transdisciplinary perspective.' In J. Gidley, \& S. Inayatullah (Eds.), Youth futures: Comparative research and transformative visions (pp. 3-18). Santa Barbara, CA: Praeger Publishers.

Good, L.K., \& Huddleston, P. (1995). 'Ethnocentrism of Polish and Russian consumers: Are feelings and intentions related.' International Marketing Review, 12(5), 35-48.

Granzin, K.L., \& Olsen, J. E. (1998). 'Americans' choice of domestic over foreign products: A matter of helping behaviour?' Journal of Business Research, 43(1), 39-54.

Han, C.M. (1989). 'Country image: Halo or summary construct?' Journal of Marketing Research, 26(2), 222-29.

Herche, J. (1994). 'Ethnocentric tendencies, marketing strategy and import purchase behaviour.' International Marketing Review, 11(3), 4-16.

Javalgi, R.G., Khare, V.P., Gross, A. C., \& Scherer, R. F. (2005). 'An application of the consumer ethnocentrism model to French consumers.' International Business Review, 14(3), 325-44.

Kaynak, E., \& Cavusgil, T. (1983). 'Consumer attitudes toward products of foreign origin: Do they vary across product classes?' International Journal of Advertising, 2(2), 147-57.

Keillor, B.D., Hult, G.T.M., Erffmeyer, R. C., \& Babakus, E. (1996). 'NATID: The development and application of a national identity measure for use in international marketing.' Journal of International Marketing, 4(2), 57-73.

Kjeldgaard, D., \& Askegaard, S. (2006). 'The glocalization of youth culture: The global youth segment as structures of common difference.' Journal of Consumer Research, 33(2), 231-47.

Lichtenstein, D.R., Ridgway, N.M., \& Netemeyer, R.G. (1993). 'Price perceptions and consumer shopping behaviour: A field study.' Journal of Marketing Research, 30(2), 234-245.

Lindquist, J.D., Vida, I., Plank, R.E., \& Fairhurst, A. (2001). 'The modified CETSCALE: Validity tests in the Czech Republic, Hungary, and Poland.' International Business Review, 10(5), 505-16.

Liu, S. S., \& Johnson, K.F. (2005). 'The automatic country-of-origin effects on brand judgments.' Journal of Advertising, 34(1), 87-97.

Lu, I.R., \& Heslop, L. (2008). 'Measuring country image: A research proposal.' Paper presented at the Annual Conference of the Administrative Sciences Association of Canada (ASAC), 24-27 May, Halifax, Nova Scotia, 29(3) 290-303. 
Nijssen, E.J., \& Douglas, S.P. (2004). 'Examining the animosity model in a country with a high level of foreign trade.' International Journal of Research in Marketing, 21(1), 23-38.

Papadopoulos, N. (2004). 'Place branding: Evolution, meaning and implications.' Place Branding, 1(1), 36-49.

Parameswaran, R., \& Pisharodi, R. M. (1994). 'Facets of country of origin image: An empirical assessment.' Journal of Advertising, 23(1), 43-56.

Reardon, J., Miller, C., Vida, I., \& Kim, I. (2005). 'The effects of ethnocentrism and economic development on the formation of brand and ad attitudes in transitional economies.' European Journal of Marketing, 39(7/8), 737-54.

Roth, K.P., \& Diamantopoulos, A. (2009). 'Advancing the country image construct.' Journal of Business Research, 62(7), 726-40.

Shankarmahesh, M.N. (2006). 'Consumer ethnocentrism: An integrative review of its antecedents and consequences.' International Marketing Review, 23(2), 146-72.

Sharma, S., Shimp, T.A., \& Shin, J. (1995). 'Consumer ethnocentrism: A test of antecedents and moderators.' Journal of the Academy of Marketing Science, 23(1), 26-37.

Shimp, T.A., \& Sharma, S. (1987). 'Consumer ethnocentrism: Construction and validation of the CETSCALE.' Journal of Marketing Research, 24, 280-89.

Singh, R.M. (2013). 'Cultural paradigm of high performing organizations: An ethnographic study in India context.' International Journal of Business Anthropology, 4(1), 92-107.

Strizhakova, Y., Coulter, R. A., \& Price, L. L. (2008). 'The meanings of branded products: A cross-national scale development and meaning assessment.' International Journal of Research in Marketing, 25(2), 82-93.

Suh, T., \& Kwon, I.G. (2002). 'Globalization and reluctant buyers.' International Marketing Review, 19(6), 663-680.

Vida, I., \& Dmitrović, T. (2001). 'An empirical analysis of consumer purchasing behaviour in former Yugoslav markets.' Economic and Business Review, 3(3/4), 191-07.

Wang, C.L., \& Chen, Z. X. (2004). 'Consumer ethnocentrism and willingness to buy domestic products in a developing country setting: Testing moderating effects.' Journal of Consumer Marketing, 21(6), 391-400.

Yelkur, R., Chakrabarty, S., \& Bandyopadhyay, S. (2006). 'Ethnocentrism and buying intentions: Does economic development matter?' Marketing Management Journal, 16(2), 26-37. 
Yeoh, E.K. (2013). 'Socioeconomic development and ethno-cultural diversity: State policy and the evolvement of pluralism in Malaysia.' International Journal of Business Anthropology, 4(1), 121-44.

Yoon, S., Cannon, H. M., \& Yaprak, A. (1996). 'Evaluating the CYMYC cosmopolitanism scale on Korean consumers.' Advances in International Marketing, 7(2), 211-32. 
